\title{
Scots law: a system in search of a family? SUE FARRAN
}

\author{
University of Dundee
}

\begin{abstract}
$\underline{\text { Abstract }}$
The concept of legal families is familiar to most comparativists and although miscegenation is an increasingly common feature in a global community, arguably an understanding of family origins may help to anticipate differences of approach, ideology, attitudes to law and diverging normative values. Classification into families, despite various criticisms and disagreements as to which families there are or how they should be distinguished, provides a useful tool for the comparativists and those seeking, reform, unification or barmonisation.

The Scottish legal system, however, is one that tends to elude classification. Even where "mixed" or "bybrid" legal systems are recognised, that of Scotland may be omitted or distinguished from those of, for example, Greece, South Africa, Israel or the Seychelles.

This begs the question, what is a legal system and how is it distinguished? This paper examines the Scottish legal system, taking as its starting point a focus on juristic style as the key distinguishing feature of a legal system and looking at the key elements that eminent comparativists Zweigert and Kötz suggest shape this. These are: the historical background and development; its typical mode of thought; its distinctive institutions; the types of legal sources it acknowledges; and its ideology. Looking particularly at the academic debates that have arisen in Scotland concerning the nature and identity of Scots law, the paper goes on to consider whether the claim to a distinct legal system is anything more than a manifestation of the fact that "each political society in the world has its own law", 1 and that in fact the time has come to abandon the notion of families.
\end{abstract}

\section{Introduction}

A the outset it might be asked why is it important that a legal system belongs to a legal family? Zweigert and Kötz suggest that for the comparativist this classification serves a useful taxonomic purpose, making the mass of legal systems more comprehensible, and facilitating comparison either by selecting systems with the same family for purposes of comparison or ensuring that dissimilar systems are compared by going outside the family. ${ }^{2}$ David suggests that the use of families helps us to overcome the diversity of legal systems and enables us to look beyond differences in the detail of rules, which may in any case

1 R David and J Brierley, Major Legal Systems in the World Today (London: Stevens 1978), p. 1.

2 K Zweigert and H Kötz, An Introduction to Comparative Law, T Weir (trans.) (Oxford: Clarendon Press 1998). 
change, to the "juridical phenomenon" behind laws, ${ }^{3}$ which have a historical continuity. Classification of legal families emerged as a feature of comparative law in the early twentieth century when it was felt that the adoption of a more scientific enquiry might facilitate the unification of laws and put comparative legal study on a more respectable footing so that its methodology could play a significant role in the movement towards a single European community and greater international legal dialogue. While these particular aspirations may have passed, today there is a focus on harmonisation of laws, especially within European private law, so there may still be justification in seeking to establish some classificatory framework within that differences and similarities can be identified.

\section{Identifying families}

For the comparativist seeking to group legal systems into families, a number of questions arise. How many families should there be? How should membership be established? What should be done about those legal systems which seem to belong to two or more families?

One approach would be to have just two families - Western and non-Western systems of law - but this might be oversimplistic in an age of global legal development and discourse. Esmein suggested five families: Romanistic, Germanic, Anglo-Saxon, Slav and Islamic. ${ }^{4}$ This, of course, ignored customary and socialist laws. Lévy-Ullman suggested three families: the continental family of laws; the English-speaking family of laws and the Islamic family - again ignoring much of African and the socialist countries. ${ }^{5}$ Sauser-Hall used race as the basis of distinction, identifying Indo-European, Semetic and Mongolian families, and those of uncivilised nations. ${ }^{6}$ Arminjon, Nolde and Wolff suggested that the key defining characteristic was difference in substance, focusing on derivation, originality and common elements, and found seven legal families: French, German, Scandinavian, English, Russian, Islamic and Hindu. ${ }^{7}$ David argued that only two distinguishing criteria were relevant: ideology and legal technique. Ideology was the consequence of religion, philosophy, political, economic and social structure - either in combination or separately which shaped the conception of justice in any legal family. David's original families were: Western systems, socialist systems, Islamic law, Hindu law and Chinese law. ${ }^{8} \mathrm{He}$ reduced these subsequently to three: Romanistic-German, common law and socialist law, with the legal systems of Jewish law, Hindu law and the laws of the Far East in "other systems", a residual category of dissimilar laws. ${ }^{9}$ In 1969, Malmström suggested, first, a European-American family, which would include Romanistic and German systems, those of Latin America and the Nordic countries and the common law system. His second family encompassed the socialist legal systems; the third the non-communist Asian systems; and

3 David and Brierley, Major Legal Systems, n. 1 above, p. 18.

4 A Esmein, "Le droit comparé et l'enseignement du droit", Congrès international de droit comparé, Procèsverbaux des séances et documents I, Paris, 1905. Esmien also suggests that the key distinguishing features should be historical sources, general structure and particular characteristics.

5 H Lévy-Ullman "Observations generals sur les communications relatives au droit privé dans les pays étrangers" in G Tarde (ed.), Les transformations du droit dans les principaux pays depuis cinquante ans, (1869-1919) (Paris: Société de législations comparé/F Pichon et Durand-Auzias 1922) based his main distinction on sources of law.

6 G Sauser-Hall, Fonction et méthode du droit comparé (Geneva: Kundig 1913). Indo-European included as subdivisions Hindu, Iranian, Celtic, Greco-Roman, Germanic, Anglo-Saxon and Lithuanian-Slav. Arguably Scots law would fall into none of these neatly.

7 P Arminjon, B Nolde and N Wolff, Traité de droit comparé (Paris: Dalloz 1950). While this included socialist systems, it excluded African customary systems and, again, where would Scots law fit in?

8 R David, Traité élémentaire de droit civil comparé (Paris: Librairie Générale de Droit 1950).

9 R David, Les grands systemes de droit contemporains (Paris: Dalloz 1982). Scots law would find itself in this residual category. 
the fourth the African systems. ${ }^{10}$ More recently, de Cruz has indicated a preference for the term "legal traditions" rather than families, using Merryman's definition of a legal tradition as a set of "deeply rooted historically conditioned attitudes about the nature of law, the role of law in society and the political ideology, the organisation and operation of a legal system". ${ }^{11}$ There is therefore, some diversity on how to classify legal systems into families.

Zweigert and Kötz highlight several difficulties that may be of particular contemporary relevance. First, whatever the parent legal system, a legal offspring may adopt a new parent(s) or affiliate with another family or families. ${ }^{12}$ Secondly, the categorisation may vary depending on whether one is considering private law or public law, or certain areas of law within these two. ${ }^{13}$ Thirdly, the time of categorisation may be crucial, especially if there is a programme of considerable legal reform - for example, codification of the law or the consolidation of unwritten customary laws into written form. Zweigert and Kötz also advocate the need to focus on the style of a legal system and its distinctive "stylistic traits" to inform groups and to decide which family a legal system belongs to. The factors they identify as "crucial for the style of a legal system or legal family" are:

- historical background and development of the law;

- predominant and characteristic mode of thought in legal matters;

- especially distinctive institutions;

- the kind of legal sources it acknowledges and the way it handles them;

- $\quad$ and its ideology. ${ }^{14}$

It is to these factors that this paper now turns to consider Scots law and the legal family it might belong to. There are several possible options that might be considered in determining the family membership of Scots law: the Romano-Germanic family of much of continental Europe; the common law family, as found in England and Wales; the mixed jurisdiction family; or a distinctive (family-less) system. These last two possibilities will be considered in due course. The initial focus will be on the common or distinct stylistic traits of Scots law when compared with that of the common law or civil law legal systems.

\section{Historical background and development}

In looking at the historical background and development of the law, the aim is to find similarities and differences in the law of Scotland and that of its near neighbour England and Wales, and its more distant possible cousins on the Continent. The historical origins of Scots law are the subject of considerable debate among Scots scholars and it is not the intention of this article to engage with that debate. What follows is a necessarily cursory treatment of the subject area. ${ }^{15}$ Possible elements are Roman law, canon law, common or customary law, feudal law, and cases and legislation from the common law of England and Wales. Elements that could be indicative of modern civil law systems are codes of law,

10 A Malmström, "The systems of legal systems, notes on a problem of classification in comparable law" (1969) 13 Scandinavian Studies in Law 127. Here Scots law could fall under his broad first family.

11 P De Cruz, Comparative Law in a Changing World (London: Cavendish 1999), p. 33, quoting Merryman 1985.

12 Consider for example, countries emerging from socialist law.

13 This is particularly evident in plural legal systems where customary or religious law may govern family life, property, inheritance etc. but a different system of law govern criminal law, the rules of procedure and evidence, or commercial law.

14 Zweigert and Kötz, An Introduction, n. 2 above, p. 68.

15 For a readable account of the history of Scots law, see J Cairns, "Historical introduction", in K Reid and R Zimmermann, A History of Private Law in Scotland, vol. 1 (Oxford: OUP 2000), pp. 14-184. 
restrictions on the powers of judges to "make" the law, reference to institutional writings, an inquisitorial system, the absence of jury trial, and a professional judiciary.

\section{ROMAN LAW}

It has been suggested that "Scots law is not . . . based entirely on Roman law", 16 even though Roman terminology - together with a predilection for quoting Latin, can be found in the caselaw. Roman law was probably introduced to fill gaps in the local law - consisting of statutes, feudal law and customary laws, but the extent to which this happened may have been exaggerated by contrast with the lack of Roman law influence in England. ${ }^{17}$ One view is that "Roman law has never been of itself authoritative in Scotland." 18 Stair stated that Roman law did not have "with us the authority of law; and therefore [is] only received according to [its] equity and expediency". ${ }^{19}$ Such Roman law as was received probably infiltrated Scotland as part of the general law of Europe, especially in mercantile law, and through canon or ecclesiastical law - which was also the case in England.

Whether Roman law remains an influence or feature of Scots law is debateable. Writing in the Scots Law Times in 2008, Cairns and du Plessis assert that Roman law is still referred to quite often in the cases that come before Scottish courts, ${ }^{20}$ however, leading modern textbooks on the Scots legal system tend to be dismissive of its contemporary relevance. ${ }^{21}$

\section{CANON LAW}

Scots law was also open to the reception of canon law from the Continent over a period of several centuries, although the influence of canon law seems to have waned from the Reformation in 1560 onwards. ${ }^{22}$ Indeed, one of the factors that contributed to law scholars studying at Orleans, and the Protestant universities of the Netherlands, was the fact that most universities taught canon and Roman law rather than civil law. ${ }^{23}$ Also, in Scotland the ecclesiastical courts had considerably more local power than those in England - where the administration of justice was strongly centralised - and canon lawyers were predominant until the fifteenth or sixteenth centuries. ${ }^{24}$ Canon law and the procedures of the church courts - where Roman law sometimes formed the basis of pleadings, ${ }^{25}$ crossed over into the secular courts, so that even when the former fell into disuse the indirect influence of Roman law via church law remained. ${ }^{26}$

16 OF Robinson, TD Fergus and WM Gordon, An Introduction to European Legal History (Abingdon: Professional Books 1985), p. 377.

17 FH Lawson quoting from the first volume of the Stair Society, "The sources and literature of Scots law" where it was said "the reputation which Scotland has perhaps acquired as a stronghold of Roman Law is an insular one, and is based on the contrast between the legal systems north and south of the Tweed": A Common Lanyer Looks at the Civil Law (Ann Arbor: University of Michigan 1953), pp. 179-82.

18 Robinson et al., An Introduction, n. 16 above, p. 377.

19 Stair, Institutes 1.1.16, quoted in Robinson et al., An Introduction, n. 16 above, p. 378.

20 J Cairns and P Du Plessis "Ten years of Roman law in Scottish courts" (2008) Scots Law Times 191.

21 R White and I Willock The Scottish Legal System 4th edn (Edinburgh: Bloomsbury Professional 2007), p. 21, suggest that the "influence of Roman law on Scots law has been very limited and spasmodic in comparison with that of English law".

22 One of the long-lasting influences of the canon law was the appointment of an executor or administrator of a deceased estate - an institution that was avoided on the Continent, where the estate vests in the heir.

23 TB Smith points out that before the Reformation churchmen took a leading role as judges in Scotland: TB Smith, Studies Critical and Comparative (Edinburgh: W Green 1962), p. 35.

24 Robinson et al., An Introduction, n. 16 above, p. 379. For example, in 1532, when the College of Justice was founded in Scotland, the Lord President and $50 \%$ of the judges were clerics.

25 For example, a claim for restitutio in integrum where a voidable contract had been entered into.

26 For example, the legitimation of children by subsequent marriage. 


\section{LOCAL (COMMON), CUSTOMARY AND FEUDAL LAW}

Any laws introduced into Scotland during the course of the thirteenth to eighteenth centuries were in addition to existing Scots law, which included its own written laws, indigenous customary laws ${ }^{27}$ - including feudal property laws influenced by the feudal law of England - and common law developed through the courts. ${ }^{28}$ Indeed, until the Middle Ages, those books of law that did exist were of feudal and customary law. ${ }^{29}$ Even when other influences were adopted or introduced, Scots law continued to develop its own "common law", moulding and adapting these various "transplants" or "transfusions". 30

\section{ENGLISH (COMMON) LAW}

In Scotland it is argued by some that the turning point in the forces that shaped Scots law was the Act of Union, ${ }^{31}$ but others indicate that there was considerable influence of English common law in Scots law long before that, ${ }^{32}$ and in any case in certain areas such as mercantile law, or feudal land law, there was much that was similar. Certainly, following union, the influence of English law accelerated in two ways. First, as regards legislation, which was made in Westminster, and secondly as regards appeals of civil cases. ${ }^{33}$ In respect of the former, rarely were the legislative needs of Scotland considered as being unique or distinct. Legislation was for the most part extended to Scotland, occasionally "kilted" to make it appear more Scottish. As regards the latter, Article XVIII of the Treaty of Union 1707, expressly preserved Scots private law while Article XIX stated quite clearly that no causes in Scotland were to be heard in the English courts or any other court sitting at Westminster Hall. However, there was no reference to the Scots role of the Appellate Committee of the House of Lords or provision as to what was to happen to those appeals from the Inner House of the Court of Session that had previously been heard by the Scots Parliament - now abolished. Following test cases in 1707 and 1709, the appeal jurisdiction of the House of Lords, for Scots civil cases, emerged. ${ }^{34}$ Consequently, Scots law cases were frequently decided by non-Scots judges (in fact until 1844 frequently by peers who had no legal training let alone any knowledge of Scots law).

\section{THE RELATIONSHIP WITH CONTINENTAL CIVIL LAW}

Scottish affinity with the Continent rather than the English was prompted by religion and politics. Certainly, the political alliance between Scotland and France - the Aulde Alliance meant that there were military and diplomatic exchanges in the period 1295-1707, and during the fourteenth and fifteenth centuries Scots lawyers went to France for their legal

27 For example, Udal law in Orkney and the Shetland Islands and Birlaw - derived from Danish or Nordic law - which governed the use of commons.

28 This was collected into judges notebooks (Practicks) one of the earliest being that of Balfour (1579).

29 Robinson et al., An Introduction, n. 16 above, p. 378.

30 See W Sellar, "The resilience of the Scottish common law" and other essays in D Carey Miller and R Zimmermann (eds), The Civilian Tradition and Scots Law (Berlin: Duncker and Humblot 1997).

31 W Sellar, for example, suggests that by the end of the thirteenth century one could talk of a lex anglicana but thereafter divergence occurred: "Scots law: mixed from the very beginning? A tale of two receptions" (2000) 4 EdinLR 3 at 7, and A Wijffels, "A British ius commune? A debate on the union of the laws of Scotland and England during the first years of James VI/I’s English reign" (2002) 6 EdinLR 315.

32 TB Smith, for example, points out that lay justices tended to borrow ideas from England, certainly until reaction against Edward I led to the alliance with France at the end of the thirteenth century: Smith, Studies Critical, n. 23 above, p. 32.

33 For a detailed review of the development of Scots law from 1701 to the end of the nineteenth century, see A Gibb, Law from over the Border: A short account of a strange jurisdiction (Edinburgh: W Green 1950).

34 Earl of Roseberrie $\mathrm{v}$ St John Inglis (1707) and Greenshields $\mathrm{v}$ Magistrates of Edinburgh (1709). 
education - to Paris, Orleans, Avignon and Louvain, bringing back with them not only continental legal ideas but also a more cosmopolitan approach to law, language and culture than perhaps was experienced in England. ${ }^{35}$

How much this ensured a "reception" of French (or civil law) in Scotland is debated. Lawson has suggested that "In Scotland there is some doubt whether any reception in the proper sense of the term ever occurred." 36 Certainly, the works of leading French writers were brought back to Scotland and informed legal argument in the fourteenth and fifteenth centuries, the availability of these treatises supplementing the lack of equivalent Scots writing until Stair. ${ }^{37}$ Law students who had studied in France, Italy, Germany or the Netherlands in the fifteenth and sixteenth centuries returned to practise law in the church and secular courts and no doubt brought back with them a number of received civil law ideas - Roman law modified by glossators, commentators, humanists and pandectists, ${ }^{38}$ and mixed with the customary laws of France, Germany and the Netherlands. Moreover, the civil law that was received was itself a hybrid law, being the law in force prior to the legal revolution of the Napoleonic (and other) codes. ${ }^{39}$ Increasingly, it was the Protestant academic institutions of the Netherlands that attracted student lawyers from Scotland, ${ }^{40}$ so that other elements of civil law - notably the Roman-Dutch law of the sixteenth and seventeenth centuries - may have influenced Scots legal thinkers. However, the Napoleonic wars at the end of the eighteenth and early nineteenth centuries put an end to the continental influence, while Napoleonic codification in France and the Netherlands marked a profound change in the legal systems of these countries. ${ }^{41}$ There was a change in the political affiliation of Scotland, and the emergence of a more developed Scottish legal system, Scottish legal education and Scottish written sources of law. ${ }^{42}$ The shift away from the civil law system of the Continent was compensated by a shift towards the common law, driven by the pace and needs of industrialisation and trade. The severance of ties with the Continent and the increasing influence of English common law on Scots law during the nineteenth century via legislation and caselaw meant that "the purity of Scots law was sullied by the introduction of English legal ideas". ${ }^{43}$ It also meant that the old institutional writers lost ground to the more specialised works. ${ }^{44}$

Early historical background may not be of particular help in distinguishing a legal system. These sources suggest a background not vastly dissimilar from many Western legal systems, in which ordinary people tended to be ruled by local laws and customs administered at a local level - often with the intervention of church or ecclesiastical law and ecclesiastical courts in

35 There were no universities in Scotland until the fifteenth century. St Andrews was founded in 1413, Glasgow in 1451 and Aberdeen in 1496. However, the teaching of law was slow to get off the ground and students continued to travel abroad to study law.

36 Lawson, A Common Lawyer, n. 17 above, p. 26

37 Although some collections of court decisions, statutes and customary laws ("aulde lawes") had been made as early at the fifteenth century.

38 The "ius commune" of Europe.

39 Including the much earlier codification of French customary law (les coutumes)

40 For example, Leyden, Utrecht and Groningen.

41 By the eighteenth century, law was more widely available at the universities in Scotland, removing the need to travel abroad.

42 Although it was intended that the early Scottish universities would offer an education in civil and canon law, this does not seem to have occurred until the late sixteenth/early seventeenth century. The civil law tradition, such as it was, was therefore one of practitioners rather than academics.

43 Zweigert and Kötz, An Introduction, n. 2 above, p. 210.

44 See, for example, Bell's Commmentaries (1800), which dealt with bankruptcy and mercantile law and drew considerably on English authorities. 
those matters that the church viewed to be of most significance, for example, family law. Property law was determined by the property-holding structure - closely linked to social structure - while the law of merchants was less constrained by local boundaries to reflect the pragmatic needs of the market place. Those who practised law either learnt their trade through apprenticeships or, if fortunate, by attending the universities.

Later developments can either bring previously distinct systems closer together (as happened with the reception of the French Civil Code in the early nineteenth century in many parts of Europe) or put asunder systems that were formerly less distinct (as has happened with the disintegration of the Soviet socialist republic). In Scotland there were several key moments at which family allegiance may have shifted. ${ }^{45}$

\section{Typical mode of thought}

Zweigert and Kötz suggest that "the Germanic and Romanistic families are marked by a tendency to use abstract legal norms, to have a well-articulated system containing well-defined areas of law and to think up and to think in juristic constructions". ${ }^{46}$ How true is this of Scots law? Writing in 1996, Osborne and Armstrong noted "One of the central articles of Scottish faith is that the Scottish legal system is of peculiar excellence and enjoys a mysterious superiority to that found in all other jurisdictions." 47 Quite what they meant is unclear. Peter Birks suggested that the distinct quality of Scots law lay in its commitment to a more systematic approach. ${ }^{48}$ Lord MacMillan suggested that the Scots lawyer had a philosophical mind while the English lawyer was concerned with procedure, remedies and precedents rather than searching for principles, ${ }^{49}$ while Mackay-Cooper, supporting continental approaches in Scots law, claimed that "the civilian puts his faith in syllogisms, the common lawyer in precedents". 50 Others have been less convinced. For example, Evans-Jones has suggested that the historical experience of Scots law has been that of a weak legal system open to the reception of other systems. ${ }^{51}$ Indeed, Lord Rodger of Earlsferry has suggested that the lack of purity in Scots legal thinking has been a strength, giving it the "advantages of the case law approach of common law, coupled with a degree of civilian rigour". 52

Certainly, while Roman law may not have been a direct source of law in Scotland, the influence of the late Roman jurists such as Justinian, is evident in the structure and arrangement of the early law books of Scots institutional writers - Stair's Institutions (1681),

45 For example, the establishment of the Court of Session in 1532; the "Wars of Independence" against Edward 1 - J Gow, The Introduction of the Theory of Justice to Scots Law (PhD thesis, University of Aberdeen 1952), p. 192; the Act of Union 1707; the French Revolution 1789; the Scotland Act 1998, as well as more drawn-out influential factors such as the industrial revolution, the growth of the British empire and a single market in Europe.

46 Zweigert and Kötz, An Introduction, n. 2 above, p. 70.

47 B Osborne and R Armstrong, Scotch Obsessions (Edinburgh: Birlinn 1996), p. 100.

48 P Birks, "More logic and less experience" in Carey Miller and Zimmermann, The Civilian Tradition, n. 30 above, p. 167.

49 Quoted in Lawson, A Common Lanyer, n. 17 above, p. 141.

50 T. Mackay-Cooper "The common and civil law - a Scot's view" (1949-50) 63 Harvard Law Review 467 at 471. In conversation it has been suggested to me that Scots law is inductive, reaching a solution by adhering to established principles, while English law is deductive, with judges having decided on the solution they wish to reach first and then justifying it by means of selected principles. Both may lead to unsatisfactory outcomes and both may require a degree of selection.

51 R Evans-Jones, "Receptions of law, mixed legal systems and the myth of the genius of Scots private law" (1998) 114 LQR 228.

52 Lord Rodger of Earlsferry: "Say not the struggle naught availeth: the costs and benefits of mixed legal systems" (2003-04) 78 Tulane Law Review 419, at 425. By contrast K Reid has been critical of the "immature ad hoc products of English law", "The idea of mixed legal systems" (2003-04) 78 Tulane Law Review 7 at 14. 
for example, has been held to be on par with the work of Grotius in the Netherlands. ${ }^{53}$ In part this may have been influenced by the attendance of Scots lawyers at the universities of France and the Netherlands where the work of the later institutional writers was central to legal education. ${ }^{54}$ However, the last of the great institutional writers died in 1843 , and as TB Smith acknowledged:

Much ... has changed since the early nineteenth century, in particular through social and economic legislation affecting the United Kingdom as a whole, and there have been other influences tending to assimilate Scottish and English judicial solutions. ${ }^{55}$

While there are some areas of Scots law that reflect juristic constructions (for example, the division of property into corporeal and incorporeal, hereditable and non-hereditable property), and there are similarities to aspects of modern civil law systems (such as the broad-based law of delict in Scots law compared to the English law of many separate torts), a number of the distinctions have become blurred in the course of the twentieth century, for example, the development of the tort/delict of negligence in both jurisdictions, a shift towards insistence on form and formality in conveyancing transactions and pragmatic accommodation of commercial needs. ${ }^{56}$

Moreover, unlike the claim that Zweigert and Kötz make for continental law, which has developed as abstract rules, Scots law, like English law, develops from caselaw, following the rule of precedent, although it has been suggested that Scots law looks to a line of precedents rather than a single one, as authority (perhaps because of the paucity of caselaw). Nevertheless, the emphasis is on the empirical rather than the abstract. ${ }^{57}$

Zweigert and Kötz also identify as distinct the antiformalism of continental systems. While Scots law never suffered from the same rigidity experienced in the common law "forms of action" and therefore had little need of equity's intervention, Scots law is formalistic, and dislikes equity's inclination to look at the intention rather than the form or to take as done that which ought to be done. However, although Scots law never experienced the parallel system of courts that occurred in England prior to the end of the nineteenth century, it would be wrong to suggest that equity is not part of Scots law, indeed it has been suggested that Stair, who offered "a reasoned and systematic approach to the science of law . . . took equity as his overriding principle". ${ }^{58}$ Moreover, it was recognised that the Privy Council of Scotland, the principal executive arm of the Crown, exercised the "equitable jurisdiction" of the Crown. ${ }^{59}$ Indeed, Walker has stated "although equity has never formed a substantive and separate part of the law of the country, manifestations of it as a basic principle underlying various branches of the law are sufficiently distinguishable". 60

53 Smith, Studies Critical, n. 23 above, p. 33.

54 Smith, for example, points to the influence of the University of Orleans: ibid. p. 28. Civilian influence on education, however, pretty much ceased in the late eighteenth century.

55 Ibid. p. 33.

56 For comment, see D Cabrelli and S Farran "Exploring the interfaces between contract law and property law: a UK comparative approach" (2006) 13(4) Maastricht Journal of European Comparative Law 403.

57 Smith, Studies Critical, n. 23 above, p. 33.

58 Robinson et al., An Introduction, n. 16 above, p. 386.

59 Ibid. p. 399, at least until the union of the parliaments and the 1708 creation of a Privy Council of Great Britain.

60 W Walker, "Equity in Scots law" (1955) Juridical Review 103, at 104. 


\section{Distinctive institutions}

One of the important style traits which Zweigert and Kötz highlight is the distinctiveness of a system that strikes the comparativist as being very different from his or her own system. If one compares Scots law with English law there are certainly some differences in specific areas of law, although often these are in form rather than the "juridical phenomena; behind the rules" - to use David's expression. So, for example, Scots law may struggle with the private trust, but it recognises contracts for the benefit of third parties, ${ }^{61}$ the fiduciary role and the possibility of enforcing promises without consideration. It may not accommodate promissory and proprietary estoppel but recognises the idea of raising a personal bar to the assertion of legal claims where to do so would lead to an unjust result. In contract, Scots law does not require consideration and therefore the gratuitous or unilateral promise is enforceable. ${ }^{62}$

Distinctively, Scots law recognises the reserved share on inheritance and restricts freedom of testation, as in civil law systems. Even here, the difference is less than it was because of the wide scope for those not provided for under freedom of testation in English law to challenge the devolution of the estate under the Inheritance (Provisions for Family and Dependents) Act 1975, but, increasingly, family law is being shaped by considerations of equality, the welfare of children and the influence of human rights considerations. ${ }^{63}$

It is true that in the administration of justice Scots law never experienced the dual system of common law and equity courts as was experienced in England and Wales until the Judicature Acts 1873-75, but this may be largely a consequence of historical chance. As Walker has opined, the civil courts in Scotland were "new and weak" in the sixteenth century, and therefore did not pose the challenge that was being experienced in England between the exercise of power by the Crown and that of the Lord Chancellor. On the other hand, development of an autonomous Scots law through the courts and legislature was severely curtailed in 1707, when not only did Scotland lose the ability to legislate for itself, but also civil cases on appeal were going to the House of Lords to be determined by English judges.

Unlike many civil law system, Scots law never had a clear division between public and private law, nor a constitutional court, so that courts of law had to develop a general competence across a broad range of topics. However, the classification of law in Scotland has tended to follow civil law traditions and in the Scotland Act 1998 this division into the law of persons, things and actions is maintained. ${ }^{64}$ Whether new legislation made under the powers conferred by the Act will continue to reflect this rather rigid classification remains to be seen.

\section{Types of legal sources}

Unlike civil law countries, Scotland never underwent codification. ${ }^{65}$ The sources of law were the customs of the people (the common law, applied in the local and later centralised courts), Scottish statutes and customary laws ("aulde lawes"). Until the union of the two

61 That, until the Contracts (Rights of Third Parties) Act 1999, English law struggled with due to the doctrine of privity of contract.

62 In English law, this can be achieved with a promise made "under seal" or in a formal covenant.

63 Both systems are for example, considering reform of succession law.

64 S. 126.

65 This may have been partly because institutional writers, such as Bell, had already "codified" the law, or because the English Parliament was unlikely ever to approve a code. In any case, there seems to have been little agitation for a code in Scotland. 
parliaments - as distinct from the union of the crowns in 1603 under James VI of Scotland (James I of England) - Scotland made its own statute law, but from 1707 until 1998 - when the Scotland Act gave Scotland back its own legislative autonomy - the Parliament in Westminster made laws for Scotland, either specifically, or more usually by extending laws for England and Wales to Scotland. ${ }^{66}$

At the outset, therefore, any claim that Scotland has to having a separate legal system is somewhat flawed by the lack of legislative autonomy experienced between 1707 and 1998 . Even post-devolution, Westminster continues to make some laws that are applicable to Scotland or adopted by the Scottish Parliament without alteration and the Scottish Law Commission works jointly with the English Law Commission on a number of projects. ${ }^{67}$ Even where the Scottish Law Commission engages separately on the reform of Scots law, the Holyrood Parliament seems at times unwilling to take up its proposals. ${ }^{68}$

As in England and Wales, and other common law systems, the decisions of the courts are an important source of law. In Scotland, the decisions of the Court of Session, ${ }^{69}$ the early composition of which more closely resembled the English courts than those in France, ${ }^{70}$ was an influential source of law from early on. As in England, early judges were either not trained in the law at all or were clerics, although the number of the latter diminished after the Reformation. ${ }^{71}$

As a smaller jurisdiction, Scotland has never had as many cases going through its courts as England and Wales and was not divided into two courts to deal with the pressure of work until 1808, when the Inner and Outer Courts of Sessions were formed (the former having appellate jurisdiction). ${ }^{72}$ There were no formal or systematic law reports until the early eighteenth century and those that did exist did not give the reasoning of individual judges until the early nineteenth century. ${ }^{73}$ The rule of precedent did not apply until around the same time. Perhaps inevitably, lawyers seeking to find solutions to novel legal questions looked south for precedents. In particular, during the industrial revolution of the late eighteenth and nineteenth centuries, when Scotland experienced industrialisation and urbanisation much faster than many European countries, there was a related increase in caselaw and legislation with Scots lawyers tending to look the jurisprudence of England and Wales for solutions.

Although Scots law reports are now more easily accessible, it is still the case that lawyers tend to draw on the jurisprudence of the common law rather than the civil law. Orücü, for example, has undertaken statistical analysis of the frequency with which Scots courts refer

66 Even prior to 1998, Scotland had its own Law Commission, established in 1965.

67 For example, joint reports have been produced on Third Parties - Rights against insurers (2001); Partnership (2003); and recent joint projects include insurance contract law, consumer remedies and a review on legislation governing level crossings.

68 A point noted by the chair of the Scottish Law Commission in his foreword to the 2008 Annual Report (Scot Law Com. No 214), p. 5, although the 2009 Annual Report reflected an improvement.

69 Which existed as a unitary court from 1532-1808 and gave one judgment.

70 Its jurisdiction was initially limited and a number of local and specialist courts existed as well as criminal courts of justiciars and sheriffs. In 1672 a centralised criminal court was established in Edinburgh - the High Court of Justiciary - but the administration of criminal justice was pretty shambolic until reforms in 1747 .

71 Lay judges, both ordinary and extraordinary continued to exist until the late eighteenth century.

72 Previously, appeal was to the Scottish Parliament but this was disbanded after the Treaty of Union, although it had been challenged prior to that in 1674. After union it was unclear where appeal lay until 1708 when the first Scottish Court of Session case was appealed to the House of Lords. This tradition continued until 2009 for civil appeals although there was no requirement that a Scots judge sit on such appeals until 1876.

73 In this respect, the law reports were much more like those in France. 
to other legal systems, ${ }^{74}$ noting that these references are predominantly to English decisions, although these are not always or invariably approved or followed. ${ }^{75}$ However, Orücü also found that where Scots courts do consider other legal systems these tend to be predominantly common law ones rather than civilian or mixed jurisdictions. Indeed, Walker has suggested that the influence of English law is insidious and creeps in by way of case citation, whereby the jurists use cases in which judges in the Court of Sessions have referred to English law. ${ }^{76}$

Like English law, therefore, the primary sources of law in Scots law are the statutes of Parliament and caselaw. However, the treatises of institutional writers are also referred to as authorities, or sources of law - although today it might be argued that reference to the Stair Memorial Encyclopaedia (SME) is little different from reference to Halsbury's Laws of England, the SME being subject to regular updates with contributions from a range of academic writers. Nevertheless, the role of academic scholars in the development of the law in Scotland from the 1600s to the1800s probably exceeded that of England and Wales. Indeed, it has been argued that Scots law recognised the value of legal scholarship long before the courts of England and Wales did so, ${ }^{77}$ and that this "strong tradition of overview literature" distinguished Scots law from English law, ${ }^{78}$ not only in the way that institutional writers rationally classified and exposed Scots law as a national law, ${ }^{79}$ but also in the way that Scots writers maintained the traditions of the Roman law jurists in the way the law was set out and organised. ${ }^{80}$ However, the contents of the treatises of institutional writers was itself usually a mixture of indigenous law, Roman law, canon law and feudal law. ${ }^{81}$ In the course of the seventeenth, eighteenth and nineteenth centuries there were a number of jurists writing whose works were influential in shaping Scots law. ${ }^{82}$ For example, the role of institutional writers, such as Stair, was significant in determining the sources and authorities

74 C McDiarmid undertook a similar study "Scots law: the turning of the tide" (1999) 3 Juridical Review 156. In 1949, D Walker found that over half the precedents cited in the first half of the twentieth century in Scots courts derived from English caselaw; "A note on precedent" (1949) Juridical Review 283, at 288 cited in McDiarmid, at 161.

75 Although, as Orücü points out, courts both sides of the border may assume that English and Scots law are the same unless evidence is brought to demonstrate otherwise. E Orücü, "Comparative law as a tool of construction in Scottish courts" (2000) Juridical Review 27.

76 D Walker, "The province of jurists determined" (1991) Juridical Review 20, at 40.

77 The earliest recorded writer seems to have been an anonymous one writing around 1300, but Walker is critical of his efforts because he appears to have drawn heavily on Glanvill's De Legibus et Consuetudinibus Angliae (1180) at 26. Compare, however, H MacQueen, "Mixture of muddle?" (1997) ZEuP 369 at 371, who points to the "pot-pourii" of legal sources found in this medieval Scots law text Regiam Majestatem. Later writers who focused on Scots law emerged in the fifteenth and sixteenth centuries, e.g. Balfour and Sinclair. Lord Roger of Earlsferry has stated "Institutional writers produced comprehensive accounts of Scots private law long before anything similar had been achieved in England.": "Only connect" (2007) 3 Juridical Review 163 at 171.

78 Birks, "More logic", n 48 above, p. 171. Birks decries later major works, such as the SME, because it is based on alphabetical ordering and therefore similar to Halsbury's Laws of England.

79 That was a feature of institutional writers throughout Europe at the time, as nation states sought to develop their own national legal systems. In England, Blackstone followed the same tradition.

80 Although there have also been suggestions that some institutional writers drew heavily on English law, especially to fill gaps in their statements of the law. See Lawson, A Common Lawyer, n. 17 above, p. 50, note 20.

81 Craig, for example, one of the earliest Scots institutional writers, wrote solely about feudal law.

82 For example, Craig, Stair, Hope, Mackenzie, Bankton, Erskine and Bell. Some of these recognised the influence of English law - such as Bell and Bankton - while others placed greater focus on Roman and civil law - such as Stair and Mackenzie - with Justinian's Institutes being an influential model for their own "Institutes". 
of Scots law, giving pre-eminence to the decisions of the Scottish Court of Sessions, and native rather than Roman or civil law. 83

The pre-eminence given to the institutional writers during the late seventeenth and early eighteenth centuries may have been both practical and political. ${ }^{84}$ Moreover, while English courts tended to adopt the view that no author could be cited until they were dead, ${ }^{85}$ in Scotland it appears that this convention was not strictly adhered to and there is evidence of living jurists being cited in court. ${ }^{86}$ Indeed, it has been suggested that the views of the institutional writers have traditionally been treated with as much weight as decisions of the Inner House of the Court of Session. Certainly, even in the course of the twentieth century, it would appear that Scottish courts were willing to cite the work of academic jurists more frequently than English courts. ${ }^{87}$ The role of academic jurists appears to have fallen into a decline in the early part of the twentieth century, and the production and use of law texts fell considerably in the period 1918-60.88 In recent decades, the situation seems to have improved due to a conscious effort to encourage and invest in legal academic writing 89 and, while no great institutional writers have emerged, at the start of the twenty-first century, Walker was able to maintain that the work of jurists in "analysing, systematising, putting into rational order, explaining, criticising the law on particular topics" remains an important influence on Scots law. 90

Nevertheless, although Scots law may claim civilian traditions, today its administration is largely similar to that found in England and Wales. Except at the lowest level, criminal and civil cases are heard in separate courts, there is no separate branch of administrative courts and no constitutional court. Judges are drawn primarily from practitioners and, unlike on the Continent, are not educated to be judges from their student days, and, since the nineteenth century, their judgments are attributable to them and not anonymous. The civil legal process is adversarial and criminal trials are before a jury. The legal profession is divided into those who have the right to appear before the highest courts - advocates - and those who instruct them and may appear before the lower courts - solicitors. The training of both branches of the profession is largely privately controlled by separate professional bodies: the Faculty of Advocates, which began to emerge in the late sixteenth century; and

83 Stair was essentially a practitioner writing for practitioners. His Institutions of the Laws of Scotland was published in 1681. In part, the importance attributed to institutional writers may be down to the scarcity of reported decisions in the eighteenth and nineteenth centuries. On the institutional writers, see D Walker, The Scottish Jurists (Edinburgh: W Green 1985).

84 Bankton's Institutes, for example, published after the Act of Union (1751-53) emphasised the integrity of Scots law as an independent national system - Robinson et al., An Introduction, n. 16 above, p. 388.

85 This convention appears to have originated from a judgment of Lord Eldon in 1814.

86 For example, Hume, Bell, Gloag, Clive and Walker.

87 See J Blackie and N Whitty, "Scots law and the new ius commune" in H MacQueen (ed.), Scots Law into the 21st Century (Edinburgh: W Green/Sweet \& Maxwell 1996), p. 81.

88 Reid, quotes D M Walker's comment that since 1918 "only half a dozen works of any consequence" had been produced. K Reid, "The third branch of the profession” in H MacQueen, Scots Law, n. 87 above, p. 43. He points out that in the period 1961-65 only 14 books on Scots law were published, compared to 43 in the period 1991-95, p. 45, Table 3.

89 By the establishment of the Scottish Universities Law Institute in 1960. It might be argued that this nationalistic approach to legal writing has been a double-edged sword, both promoting and restricting the publication of legal works in Scotland.

90 DMA Walker, Legal History of Scotland: The twentieth century, vol. 7 (London and Edinburgh: LexisNexis 2004), p. 1149. Others have been more critical of the "canonisation" of the institutional writers - see K Reid in Reid and Zimmermann, A History, n. 15 above, pp. 11-12. 
more recently (1949), the Law Society of Scotland. ${ }^{91}$ Although the notary was and continues to be a more common figure in Scotland than in England and Wales, the conseil juridique is unknown. From early on, the Faculty of Advocates wielded considerable power in controlling admission to the profession, including examining potential entrants in Roman law. ${ }^{92}$ Much legal training was also undertaken by members of the Faculty of Advocates, as the Scottish universities did not offer a legal education until the 1700s. ${ }^{93}$ Today, most legal training takes place away from the profession, in universities offering full-time and part-time law degrees and making provision in the legal diploma for the training of Scots lawyers. However, the Faculty of Advocates retains its monopoly on the training and admission of advocates to the Bar.

\section{Ideology}

Zweigert and Kötz suggest that in Western or European systems ideology is less likely to be a distinguishing characteristic compared to socialist systems, or those based on religious law, or where law is seen as being of secondary importance to other regulatory frameworks such as social cohesion, family honour, and what today might be referred to as alternative dispute resolution in traditional societies. ${ }^{94}$

In the case of Scotland it might be argued that the ideology behind the claim to a distinct Scottish legal system and law has been fostered by particular historical and political events, and, in a small jurisdiction, by the advocacy of notable individuals, such as TB Smith, Lord Hooper and more recently perhaps KGC Reid. ${ }^{95}$

Today, events beyond Scotland are providing a platform for the assertion of Scottish difference. Notably initiatives in Europe to arrive at a modern ius commune in many areas of private law have provided the opportunity for advocates to assert that Scots law and Scots lawyers are ideally placed to understand how best to negotiate between civil and common law systems. 96 Ironically, while the "purists" of Scots law may find the claim to miscegenation difficult to swallow, those who have asserted that Scots law was always a weak legal system, subject to many influences, ${ }^{97}$ may now find themselves in a position where that perceived weakness can now be claimed as a strength, enabling Scots law-makers to be open to harmonisation ideas and demonstrate an ability to "pick-and-mix" from different legal systems.

There is, of course, a risk that harmonisation or unification - the triumph of pragmatism over idealism - will undermine small jurisdictions. This impetus, plus perhaps the danger of being ignored altogether by projects that fail to recall that the United Kingdom does not have just one legal system, has led to recent more vocal claims that there is a "third legal family", the mixed legal systems of laws.

91 Clerical pleaders appeared before some of the medieval church courts, and procurators in the lower courts from the sixteenth century onwards. The profession of writers to the signet emerged in the sixteenth century, forming their own professional association. Procurators, notaries and writers to the signet gradually merged under the umbrella of "solicitors".

92 Competence in Scots law as an entry requirement was not compulsory until 1750.

93 Even then, chairs in Scots law lagged behind and the LLB did not become a full-time degree until the 1960 s.

94 For example, for a long time, recourse to the law in Japan was seen as being highly undesirable.

95 Not always supported by their peers. For example, Whitty says of TB Smith "his crusade was a lonely campaign": N Whitty "The civilian tradition and debates on Scots law" (1996) TS AR 446, 556.

96 See, for example, H MacQueen, "Scots law and the road to the new ius commune' (2000) 4(4) EJCL December, www.ejcl.org/ejc/44/art44-1.html.

97 See, for example, R Evans-Jones, "Receptions of law, mixed legal systems and the myth of the genius of Scots private law" (1998) 114 LQR 228. 


\section{The emergence of mixed legal systems}

Zweigert and Kötz indicate that there are some "hybrid" systems that do not fit easily into families. Among these they include: the American state of Louisiana; the Canadian province of Quebec, South Africa, Israel, the Philippines, Puerto Rico, the People's Republic of China and Scotland. ${ }^{98}$ These, they suggest may claim one parent family for some aspects of their legal system and another for others.

Despite being notably absent in the classifications of early comparativists, it might be argued that the emergence of a new family, that of mixed legal systems, has given Scots law a home. The common denominator among such systems is a legal system "in which a basically civilian system has been under pressure from the Anglo-American Common law and has in part been overlaid by that rival system of jurisprudence". 99 However, the defining characteristics of mixed legal systems are not always agreed on. ${ }^{100}$ To some extent almost all legal systems are mixed, as a result of reception, imposition, adaptation and borrowing. ${ }^{101}$ Any ius commune that emerges in the twenty-first century will be as mixed as that experienced prior to the Reformation. A more restrictive categorisation of mixed legal systems includes South Africa, Scotland, Louisiana and Quebec, which are singled out as being "classically" mixed systems, combining elements of Romano-Germanic and AngloAmerican families of laws. ${ }^{102}$

From the Scottish perspective, links with legal systems of Louisiana, South Africa and the Netherlands had been recognised and maintained quite early on. TB Smith, for example, brought over jurists from Quebec, Louisiana, the Netherlands and South Africa to teach at Edinburgh in the 1950s, and gave a complete collection of South African Law Reports to the library of the Faculty of Advocates. Although Smith's example of nurturing links with other "mixed jurisdictions" has not always been so energetically fostered, ${ }^{103}$ in recent years greater efforts have been made to develop a sense of solidarity among the members of this family. ${ }^{104}$ In part, this has been helped by increasing interest in the Europeanisation of laws

98 De Cruz's list of hybrid or mixed jurisdictions is different. He includes: the Seychelles, South Africa, Louisiana, the Philippines, Greece, Quebec and Puerto Rico. Scotland is not included, nor is Israel.

99 TB Smith addressing the Louisiana State Law Institute in 1965: A Yiannopoulus (ed), Civil Law in the Modern World (Baton Rouge: Louisiana State University Press 1965), p. 5, although even Smith recognised this as an oversimplistic definition. See, more recently, I Castellucci, "How mixed must a mixed system be?" (2008) 12(1) EJCL 13.

100 See V Palmer, Mixed Jurisdictions Worldwide: The third legal family (Cambridge: CUP 2001), and E Orücü, "What is a mixed legal system: exclusion or expansion?" (2008) 12(1) EJCL May, www.ejcl.org.

$101 \mathrm{~J}$ du Plessis, "The promises and pitfalls of mixed legal systems: the South African and Scottish experiences" (1983) 3 Stellenbosch Law Review 339.

102 Palmer, Mixed Jurisdictions, n. 100 above, p. 8. Palmer suggests that the test for admission into this select class is specificity of the admixture; appropriate (unspecified) quantification attributable to each system; distinguishable structural divisions in which the civil law applies to the private sphere and the common (Anglo-American) law to the public sphere. For comment on the difficulties of applying theses tests, see J Smits "Mixed jurisdictions: lessons for European harmonisation?" (2008) 12(1) EJCL 7, and more generally, E Orücü, E Attwooll and S Coyle (eds), Studies in Legal Systems: Mixed and mixing (The Hague: Kluwer Law International 1996).

103 N Whitty, for example, highlights the failure of Scots law to pay greater attention to South African law, "The civilian tradition and debates of Scots law" (1996) 3 TS AR 442 at 455, a view shared by P du Plessis "Innkeeper's liability for loss suffered by guests" (2007) 11 EdinLR 89. This does not diminish, however, the importance of the work of D Carey Miller, K Reid and E Reid or Whitty himself, nor the contribution of R Zimmerman, S Visser and J du Plessis, all of whom have drawn on South African/Scots comparisons.

104 See, for example, publications in the 1990s by Orücü et al., Studies in Legal Systems, n. 102 above; R Jagtenberg, E Orücü and AJ de Roo, Introduction to Comparative Law (Arnhem: Gouda Quint BV 1995); and Palmer, Mixed Jurisdictions, n. 100 above. 
and a realisation that those systems that straddle the civil law and the common law may be well placed to take a lead in such initiatives. In 2002 the First Worldwide Congress on Mixed Jurisdictions was held in Louisiana, ${ }^{105}$ and the first decade of the twenty-first century has seen a number of publications edited or co-edited by academics from Scottish universities. ${ }^{106}$ A World Society of Mixed Jurisdiction Jurists has been formed to study and promote mixed legal systems.

To what extent the emergence of a "third legal family" goes beyond academic engagement is debateable. In particular, it is unclear whether, if at all, these initiatives will impact on the teaching and practice of law in Scotland. While Roman law remains a compulsory subject of study for those wishing to qualify as advocates, it is not for those hoping to become solicitors and, in any case, the study of Roman law tends to be preJustinian. There is no requirement for law students to study modern civil law systems, or to take languages in order to access legal material from other civilian systems. ${ }^{107}$ Similarly, there is no requirement for law students to engage in comparative legal studies and, while the Scottish Law Commission is mandated by statute to do so where appropriate, there is no requirement to look to other mixed systems. The question arises therefore whether the emergence of a mixed legal family as a third legal family is anything more than an academic exercise, prompted in part by the threat of extinction. ${ }^{108}$

There are, moreover, considerable differences between the members of this mixed family. Louisiana and Quebec, for example, have codified systems; South Africa has a written constitution, a constitutional court and a federal system of provincial courts. ${ }^{109} \mathrm{It}$ also has a clearly plural legal system, with English law historically evident in clearly demarcated areas of law, such as evidence and procedure, while Roman-Dutch law permeates the law of persons and things. ${ }^{110}$ Moreover, due to historical and political division, different provinces adopted different law and legal approaches. ${ }^{111}$ Furthermore, in most mixed systems, considerations of overarching national importance - whether of Canada, the United States, South Africa or the United Kingdom - tend to predominate in a number of areas and cannot accommodate localised distinctions. Consequently, the mixed system on closer examination only relates to parts of that system, calling into question

105 The second was held in Edinburgh in 2007. For papers, see (2008)12(1) EJCL www.ejcl.org/121/issue121.html.

106 For example, V Palmer and E Reid (eds), Mixed Jurisdictions Compared (Edinburgh: Edinburgh University Press 2009), which looks at the Scotland/Louisiana comparison, and R Zimmermann, D Visser and K Reid (eds), Mixed Legal Systems in Comparative Perspective (Oxford: OUP 2005), which compares Scotland and South Africa.

107 Nor to have Latin, despite its use in the courts. Compare, for example, the requirement in South Africa where it used to be compulsory to have Latin, English and Afrikaans and remains a requirement to have at least two recognised South African languages - which now include indigenous languages.

108 See, for example, comments by K Reid, “The idea of mixed legal systems” (2003-04) 78 Tulane Law Review 14, who describes the situation of Scotland and Louisiana as "two small islands of the civil law surrounded by an ocean of common law", and possibly in danger of rising sea-levels.

109 These and other differences were noted by Zweigert and Kötz, n. 2 above, p. 204.

110 South African law was also shaped, similarly to Scots law, by political considerations, the Afrikaans universities and academics resisting the incursions of English law, a conflict that spilled over into the courts and was reflected in the political structure of the country until the overthrow of the National Party government.

111 For example, there were considerable difference between the laws in force in the English-speaking province of Natal (where, for example, there was a code of Bantu law) compared to those of the Cape (where the Dutch settlers first established themselves and introduced Roman-Dutch law), and later the Transvaal and Orange Free State (which were largely Afrikaans dominated). 
whether in fact there is a distinct legal system, or only certain distinct laws and institutions in particular parts of the system. ${ }^{112}$

However, the emergence of the concept of mixed legal systems as a family suggests that there is more to it than functionality, and begs the question whether legal systems need families to support a sense of legal community and solidarity, especially, as is often the case in hybrid systems, when certain elements are "at risk". ${ }^{113}$ Indeed, the impetus behind crosscomparative studies among mixed jurisdictions may well have been prompted by the "perils of isolation and steady assimilation by the Common Law". ${ }^{114}$

\section{Conclusion}

If one considers the example of Scotland, there are clearly challenges to defining what is meant by a legal system or legal tradition, and whether looking to the law alone (its sources, institutions, procedures, court systems, legal officers and legal education) is enough. Perhaps it is important to be mindful of de Cruz's warning that "political, economic, social and moral factors all exert considerable influence on the profile of a legal system". 115 In the case of Scotland, while the economic, social and moral factors may not appear to be significantly distinctive, compared, for example, to England and Wales or even a number of continental countries, politics may be the key to the Scottish legal tradition and the claim to Scottish difference. This does not necessarily mean that a legal system is no more than a manifestation of nationalism and legal parochialism, ${ }^{116}$ but it may mean that legal systems are more a product of cultural, political and historical orientation, rather than laws and lawyers, although the latter may themselves have a political agenda and wield considerable influence. ${ }^{117}$ Certainly, in the case of Scotland, it is these elements that may account for claims of a distinct Scots legal system, rather than any clearly distinctive stylistic traits.

Looking forward, it might be asked: what is the vision of Scots law? One advantage that might be derived from claiming membership to the mixed legal system of laws is that lawmakers can select from or draw inspiration from several component sources. ${ }^{118}$ However, consideration of the work of the Scottish Law Commission post-devolution suggests that this advantage is underutilised. ${ }^{119}$ The Scottish Parliament makes laws for Scotland under the devolved powers conferred by the Scotland Act 1998, but it also adopts Westminster

112 This raises the question of conceptual confusion between "mixed legal systems" and "plural legal systems", which goes beyond the scope of this paper but is certainly worthy of analysis. See further M Delmas-Marty, Towards a Truly Common Law: Europe as a laboratory for legal pluralism (Cambridge: CUP 2002).

113 For example, because of language of linked resources (French in Quebec and Louisiana); the infiltration of lawyers/judges trained in the predominant system; the replacement of common law by unifying statutes or law reform that obliterates differences.

114 Palmer and Reid, Mixed Jurisdictions, n. 106 above, p. vii.

115 De Cruz, Comparative Law, n. 11 above, p. 35.

116 Although, as Reid acknowledges "nationalism has played its part": Reid and Zimmermann, A History, n. 15 above, p. 6.

117 The Faculty of Advocates in Scotland is an example, but see also some of the leading Afrikaans judges and academic writers in South Africa and their influence on the Roman-Dutch aspects of South African law.

118 As stated by T Mackay-Cooper "A seat on the fence may not be a very secure seat, but it offers the conspicuous advantage of a view on both sides of the fence": "The common and civil law - a Scot's view" (1949-50) 63 Harvard Law Review 468.

119 In the 2008 Annual Report for the Scottish Law Commission, for example, comparative reference is made to the New Zealand Personal Properties Securities Act 1999 in the context of considering assignation of and security over incorporeal moveable property, and the German system of priority notices in the German land register in the context of considering reform of land registration. The 2009 Annual Report makes no reference to comparative models. 
laws, and while some of its legislation appears to have a particular Scottish stamp to it, ${ }^{120}$ much of it does not.

Scots law continues to be taught as a distinct legal system in Scottish universities and, while most of these offer courses in Roman law, few offer courses in civil law. Increasingly Scottish academic legal education is characterised by modules focusing on European and international law, and many academics are themselves not Scots and do not come from a Scottish legal background. ${ }^{121}$ While the legal profession continues to be regulated separately in Scotland from that of England and Wales, qualified solicitors from the latter can convert and practise in Scotland, and vice versa, and the "winds of change" are blowing through the monopoly that the profession has had on the provision of legal services. It is true that judges for Scottish courts are drawn largely from Scottish legal practitioners, but Scottish judges also sat on the Appellate Committee of the House of Lords and now sit in the Supreme Court of the United Kingdom - where they are considerably outnumbered by English judges. Despite the Scottish legal training of lawyers and judges, English court decisions continue to be referred to more often than those from other civil or mixed legal systems, which are hardly referred to at all. Indeed, pragmatically it has been pointed out that:

Few practitioners or judges in Scotland actually have any intellectual commitment to maintaining or cherishing Roman or civil law elements. They would say that they have enough difficulty in reaching a satisfactory answer to any given legal problem without worrying unduly as to whether they have got the Roman-English law mix right. ${ }^{122}$

This does not necessarily undermine the strength of Scots law as a legal system. It does, however, make it increasingly difficult to pinpoint its familial affiliation. Perhaps the case of the Scottish legal system suggests that it is time to abandon families, at least in their traditional form, ${ }^{123}$ and move to a more functional approach to resolve contemporary legal challenges without being "hung up" over the ancestry of the proposed solutions.

120 A colleague assures me that environmental law does so, which is interesting as it does not easily fit civilian categorisation of law, being partly public and partly private; partly about property, and persons and remedies.

121 Although an increasing number of younger academics come from continental Europe and might be prevailed upon to provide a greater comparative dimension to legal education.

122 JW Cairns and P du Plessis, "Ten years of Roman law in Scottish courts' (2008) 29 SLT 191.

123 This is a view supported by Orücü, "What is a mixed legal system", n. 100 above, although she retains the concept of family in her "family trees". 
